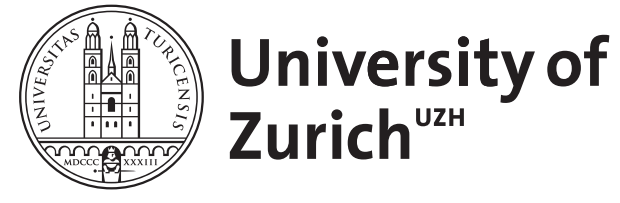

\title{
War and Natural Resource Exploitation
}

Rohner, Dominic ; van der Ploeg, Frederick

\begin{abstract}
We build a theoretical framework that allows for endogenous conflict behaviour (i.e., fighting efforts) and for endogenous natural resource exploitation (i.e., speed, ownership, and investments). While depletion is spread in a balanced Hotelling fashion during peace, the presence of conflict creates incentives for rapacious extraction, as this lowers the stakes of future contest. This voracious extraction depresses total oil revenue, especially if world oil demand is relatively elastic and the government's weapon advantage is weak. Some of these political distortions can be overcome by bribing rebels or by government investment in weapons. The shadow of conflict can also make less efficient nationalized oil extraction more attractive than private extraction, as insecure property rights create a holdup problem for the private firm and lead to a lower license fee. Furthermore, the government fights less intensely than the rebels under private exploitation, which leads to more government turnover. Without credible commitment to future fighting efforts, private oil depletion is only lucrative if the government's non-oil office rents are large and weaponry powerful, which guarantees the government a stronger grip on office and makes the holdup problem less severe.
\end{abstract}

DOI: https://doi.org/10.1016/j.euroecorev.2012.09.003

Posted at the Zurich Open Repository and Archive, University of Zurich

ZORA URL: https://doi.org/10.5167/uzh-74284

Journal Article

Accepted Version

Originally published at:

Rohner, Dominic; van der Ploeg, Frederick (2012). War and Natural Resource Exploitation. European Economic Review, 56(8):1714-1729.

DOI: https://doi.org/10.1016/j.euroecorev.2012.09.003 


\title{
War and Natural Resource Exploitation
}

\author{
Frederick van der Ploeg, University of Oxford ${ }^{*}$ and \\ Dominic Rohner, University of Zurich ${ }^{* *}$
}

\begin{abstract}
We build a theoretical framework that allows for endogenous conflict behaviour (i.e., fighting efforts) and for endogenous natural resource exploitation (i.e., speed, ownership, and investments). While depletion is spread in a balanced Hotelling fashion during peace, the presence of conflict creates incentives for rapacious extraction, as this lowers the stakes of future contest. This voracious extraction depresses total oil revenue, especially if world oil demand is relatively elastic and the government's weapon advantage is weak. Some of these political distortions can be overcome by bribing rebels or by government investment in weapons. The shadow of conflict can also make less efficient nationalized oil extraction more attractive than private extraction, as insecure property rights create a holdup problem for the private firm and lead to a lower license fee. Furthermore, the government fights less intensely than the rebels under private exploitation, which leads to more government turnover. Without credible commitment to future fighting efforts, private oil depletion is only lucrative if the government's non-oil office rents are large and weaponry powerful, which guarantees the government a stronger grip on office and makes the holdup problem less severe.
\end{abstract}

Keywords: conflict, natural resources, voracious extraction, private resource exploitation, exploration investment, license fee, rebels.

JEL codes: D45, D74, L71, Q34.

Revised 10 July 2012

\footnotetext{
* University of Oxford, OxCarre, Department of Economics, Manor Road, Oxford, OX1 3UQ, United Kingdom, rick.vanderploeg@economics.ox.ac.uk. Also affiliated with the VU University Amsterdam, Tinbergen Institute, CEPR and CESifo.

${ }^{* *}$ University of Zurich, Department of Economics, Mühlebachstrasse 86, CH-8008 Zurich, Switzerland, dominic.rohner@econ.uzh.ch. Also affiliated with OxCarre at the University of Oxford.
} 


\section{Introduction}

Natural resource abundance and exploitation fuel political unrest if different factions in society try to get control of the resource rents. ${ }^{1}$ Natural resource wealth thus increases the potential gains of controlling political power. However, conflict also affects natural resource extraction. Political instability pushes governments to rapacious resource depletion, but also reduces the incentive of especially private oil companies to explore and extract. Conflict thus influences economic decisions with respect to the method and intensity of natural resource extraction. So far the two directions of causality have been analyzed largely independently. While the literature on conflict and rent seeking has mostly treated natural resource extraction as exogenous and has focused on explaining appropriation efforts and outcomes (e.g., Torvik, 2002; Collier and Hoeffler, 2004; Fearon, 2005; Mehlum et al., 2006; Besley and Persson, 2011; Rohner, 2011), the literature on resource economics has investigated the impact of insecure property rights on extraction rates without taking into account the effects of natural resources on fighting decisions (e.g., Tornell and Lane, 1999; van der Ploeg, 2010).

Our objective is to investigate the two-way interaction between natural resource extraction and conflict. We therefore construct what to the best of our knowledge is the first unified framework with both endogenous fighting decisions and an endogenous choice of method and intensity of extraction. This enables us to derive predictions on the relative and absolute levels of fighting effort, the odds of victory, the method of and investment level in resource extraction, the speed of depletion, the size of license fees, as well as the total amounts and payoffs from extraction received by the government, rebel factions and international extraction companies.

Our analysis generates a rich set of interesting and empirically relevant predictions. The primary distortion in our setting is that the government and the rebels cannot credibly commit to a cooperative outcome with both groups renouncing fighting and committing to transfers. To address this distortion, second-best policies become optimal. First, the speed of resource extraction is affected. While in a first best world without political instability it would always be optimal to extract resources in a balanced way that spreads out depletion over all periods, in a world of anarchy it is optimal to engage in rapacious overextraction in order to reduce future rents and the incentives for rebel fighting, especially if the elasticity of world demand for resources is high and the government's weapon arsenal is small.

Also the ownership of resource production is distorted. In a world without threat from rebellion it is optimal to sell exploitation rights of natural resources to the technically most efficient company, which

\footnotetext{
${ }^{1}$ In this paper we focus on exhaustible natural resources, and in particular petrol and minerals. We will often refer to natural resources as simply oil.
} 
typically is a big private multinational. In contrast, if rebels fight for taking over the state and in case of victory renege on the past government's oil contracts, this creates a hold-up problem for private investors. The bad property rights protection depresses their initial drilling investment, and also the licence fees that private companies are willing to pay are lower, especially if the government has bad weaponry and the spoils from office are small. This in turns makes private extraction relatively less attractive for the national government, even if on purely economic grounds private depletion by an international oil company would be the first best.

In fact, if the government can commit in advance to future fighting efforts, it can reduce the political instability's negative impact on private extraction. But if the government is bound to its exploitation contracts and treats received licence fees as sunk, it always has incentives to fight less. This time inconsistency problem of the government implies that if extraction is delegated to a private company, the government's perceived stakes of keeping power are smaller than the stakes for the rebels, as the latter aim not only to appropriate rents from office, but also to expropriate the private exploitation company. This asymmetry of stakes implies that rebels fight harder than the government under private extraction, while the stakes and fighting efforts are symmetric under nationalized depletion. Hence, we predict government turnover to be higher under private than under nationalized resource depletion. These results might contribute to our understanding of the trend towards nationalized oil companies and the demise of the big multinational oil enterprises (the 'Seven Sisters') despite strong empirical evidence that private international oil companies are typically much more efficient than national oil firms. ${ }^{2}$

Besides characterizing the optimal fighting efforts and resulting winning probabilities for the various extraction speed and ownership options, and deriving what extraction speed and method is selected in equilibrium, our paper analyses more complex oil contracts, endogenizes oil exploration and shows that social transfer policies that "bribe" the rebels to work rather than fight can reduce conflict. As discussed in detail below, our results can address various empirical puzzles.

Our paper builds on the economic literature on contests and conflict pioneered by Hirshleifer (1991a), who has established that conflict efforts are increasing in the stakes of contest and the decisiveness of conflict technology. Further, poorer or less productive groups tend to fight harder and hence can have a higher winning probability than richer or more productive groups (e.g. Hirshleifer, 1991a, 1991b; Skaperdas, 1992). Favourite (respectively, underdog) groups with a probability of winning above (respectively, below) $1 / 2$ will select a higher (respectively, lower) effort level if they can pre-commit and

\footnotetext{
${ }^{2}$ There is substantial empirical evidence that international oil companies are more efficient on a variety of indicators and yield higher returns than nationalized oil companies (Al-Obaidan and Scully, 1991; Victor, 2007; Wolf, 2009; Eller et al., 2011).
} 
move first as Stackelberg leader compared to a simultaneous Nash Equilibrium without commitment (Dixit, 1987). Whether governments can pre-commit or not and the timing of decisions thus has a decisive influence on outcomes. With endogenous choice of the timing of moves, the underdog will always move first in equilibrium, so that there will always be under-commitment of efforts with respect to the benchmark without commitment (Baik and Shogren, 1992). ${ }^{3}$ An excellent survey of the literature on contests is provided by Konrad (2009).

There are few theoretical papers linking natural resource exploitation and civil war. Most focus on how larger natural resource stocks increase the incentives for rent seeking and appropriation by boosting the "prize" to be appropriated (Torvik, 2002; Grossman and Mendoza, 2003; Olsson and Fors, 2004; Maxwell and Reuveny, 2005; Hodler, 2006). ${ }^{4}$ The geographic location of resource deposits also affects conflict. For example, civil wars are more likely if resources are relatively abundant in the homelands of ethnic minorities, especially if these groups are geographically concentrated (Morelli and Rohner, 2011). Also, two countries with a shared border engage more often in inter-state war if one of them has its oil deposits close to the border and the other has no oil or deposits located far away from the border (Caselli et al., 2011).

However, none of these studies endogenizes resource extraction. Natural resource exploitation is not modeled and resources are simply treated as exogenous lump-sum rents that can be appropriated. Extraction method, ownership and speed of extraction are all abstracted from. Our main objective is to endogenize natural resource depletion in a conflict framework, and to model explicitly the extraction speed, ownership, contracts and investment of the exploration companies. Another strand of the theoretical literature analyzes how over-extraction of natural resources can result from uncertainty about property rights (Hotte, 2001, 2005) or future political outcomes (Robinson et al., 2006), but does not distinguish private versus nationalized extraction methods and does not analyze civil conflict. ${ }^{5}$

\footnotetext{
${ }^{3}$ Asymmetric information can also lead to asymmetric information contests (Hurley and Shogren, 1998).

${ }^{4}$ Fearon (2005) argues that natural resources can foster conflict by weakening state capacity. Acemoglu et al. (2012) show that price-taking firms fail to internalize the impact of their extraction on military action, which increases war incentives if resource demand is inelastic. They also link resource extraction to trade and inter-state wars. Esteban et al. (2011) argue that mass killings of unarmed civilians have a strategic component if group sizes matter for future rent sharing and that they are more likely if a large part of appropriative wealth is independent of the population size (e.g., when natural resource rents take up a large share).

${ }^{5}$ Rohner (2006) shows how resources affect fighting, but does not take into account the choice of extraction technologies, non-linear fighting technologies or asymmetries between government and rebels. Gonzales (2005) shows that it can be in the interest of conflicting factions to pick low productivity even if higher productivity was available at no cost, so as to be in a better position during distributive conflict. His setting, however, neither features natural resources nor treats issues of depletion speed and private versus nationalized production. In recent related and independent research, Janus (2012) builds an interesting model where oil needs to be extracted and sold during conflict, groups invest time in farming, resource extraction and fighting, agricultural earnings finance only
} 
The existing empirical literature on the impact of natural resources on the onset of civil war was pioneered by Collier and Hoeffler (2004) ${ }^{6}$, who found that an intermediate (rather than a small or large) ratio of primary commodity exports over GDP increases the risk of civil war. The robustness of this finding has been disputed (Fearon, 2005). For example, as our results highlight, conflict might induce rapacious depletion and thus increase current resource stakes at the expense of future stakes so that this type of econometric work needs to tackle the problem of causality. Still, it is widely accepted that some natural resources are more conducive to war than others. In particular, diamonds (Lujala et al., 2005; Humphreys, 2005; Ross, 2006; Lujala, 2010), oil (De Soysa, 2002; Fearon and Laitin, 2003; Ross, 2004, 2006; Fearon, 2005; Humphreys, 2005) and narcotics (Angrist and Kugler, 2008; Lujala, 2009) increase the risk of civil conflict onsets. Further, lootable resources such as alluvial gemstones, narcotics and timber tend to sustain and prolong war effort during conflict (Fearon, 2004; Ross, 2004, 2006; Lujala, 2010). Trade and commodity price shocks have also been found to lead to conflict in some instances (Ross, 2006; Besley and Persson, 2011; Brückner and Ciccone, 2010; Dube and Vargas, 2011). ${ }^{7}$

Our framework offers an alternative to the early results on optimal resource extraction under uncertainty about nationalization of resource stocks (Long, 1975). Here the so-called hazard rate is the probability that an extraction firm gets nationalized. ${ }^{8}$ A higher hazard rate can lead to more aggressive depletion of natural resources (cf., Long, 1975; Sinn, 1984; Konrad et al., 1994). In our framework the hazard rate corresponds to the probability that the incumbent gets removed from office. Our contribution is to make this hazard rate endogenous and to give a strategic underpinning of this hazard rate. In contrast, the hazard rate in this earlier literature is exogenous and non-strategic. In common with this earlier literature, we find that the threat of expropriation can speed up depletion but explain this as the outcome of a game.

There is also a small empirical literature on how exogenous political instability affects resource extraction. On the one hand, insecure property rights lead to excessive deforestation (Deacon, 1999; Bohn and Deacon, 2000). On the other hand, for other natural resources that need more investment and a more sophisticated extraction technology, ownership risk can result in inefficiently low investment and extraction, e.g. oil drilling is reduced in more risky countries (Bohn and Deacon, 2000). Deacon and Mueller (2006, page 136) summarize these empirical findings as follows: "In simple situations, insecure tenure for resource stocks leads to premature and excessive depletion. When resource extraction is capital

subsistence needs, and conflict activities depend on both labour and capital inputs. In contrast to our model, Janus (2012) abstracts from issues of depletion speed and privatized versus nationalized extraction.

${ }^{6}$ Recently, this has been extended with more recent data and additional independent variables (Collier et al., 2009).

${ }^{7}$ Relevant in this context is also that oil and non-lootable diamonds boost duration of political parties in autocracies, but not in democracies (Andersen and Aslaksen, 2011).

${ }^{8}$ Hazard rates are also used to explain the impact of political risk on foreign investment (Cherian and Perotti, 2001). 
intensive, however, insecure ownership can raise extraction costs and diminish or eliminate the incentive to deplete resource stock." This empirical literature takes political instability and property rights protection as exogenous. Our model suggests, however, that ignoring the bi-directional causality links between natural resources and conflict biases estimates.

In section 2 we set up the basic model of conflict and resource exploitation under nationalized extraction, while section 3 derives the result that conflict induces rapacious extraction. Section 4 treats the potential merit of bribing rebels. Section 5 focuses on private extraction and considers alternative contract arrangements for the extraction of natural resources, and allows for endogenous private oil investments. Section 6 discusses more complex oil exploration contracts and section 7 concludes and suggests various directions for further research.

\section{A Model of Conflict and Public Resource Exploitation}

We consider a two-period, resource-rich economy with a government $G$ whose term of office at the end of the first period is contested by rebels $R .{ }^{9} \mathrm{We}$ assume, for simplicity, that both the rate of interest and the time preference of the government equal zero. There is a given total stock of exhaustible resources $S>0$ which can be depleted either in period $1, S_{1}$, or in period $2, S_{2}$. Our model applies to all natural resources with a fixed stock that can be extracted at different points in time (e.g., petrol or minerals). The resource depletion constraint is thus given by:

$$
S_{1}+S_{2} \leq S, \quad S_{1} \geq 0, \quad S_{2} \geq 0
$$

There are no variable costs of extraction. We require a concave profit function for our results. This can result from elastic resource demand or from a convex extraction cost function. For reasons of analytical convenience, we choose the former. World demand for the country's resources in each period is thus given by an iso-elastic demand schedule, $S_{t}=p_{t}^{-\varepsilon}, t=1,2$, where the elasticity of demand satisfies $\varepsilon>1$. Although demand for oil and other natural resources by firms for production purposes is generally fairly inelastic, what matters for a small resource exporter is that it is to a large extent a price taker on the world market in the sense that it will lose market share in the world oil market if it sets its oil price above the

\footnotetext{
${ }^{9}$ We abstract from multiple rebel factions. We also abstract from the possibility of repression where war is prevented by deterring rebels with government armies. This would yield no war for low, repression for intermediate, and war for high values of oil revenues, and requires a degree of representative or consensual political institutions proxied by having to also pay something to rival groups whenever transfers are made to the own group - as well as asymmetry in the effects of the armed forces being raised on the probability of staying in power (Besley and Persson, 2011). If political institutions are to some extent consensual, we find that this gives incentives for more balanced depletion.
} 
world oil price. If $\varepsilon>1$ is the own price elasticity for the demand of an individual oil-producing firm and $0<\varepsilon^{C}<\varepsilon$ the cross price elasticity for the demand of an individual oil-producing firm, then a $1 \%$ increase in its own price of oil reduces its oil demand by $\varepsilon \%$ and a $1 \%$ increase in the price of oil of its competitors boosts its oil demand by $\varepsilon^{C} \%$. The aggregate price elasticity of oil demand relevant when all oil firms increase their price is then equal to $\varepsilon-\varepsilon^{c}$, which is likely to be less than one in line with empirical findings that aggregate oil demand for individual countries is quite inelastic (e.g., Cooper, 2003). In the literature various influential articles have modeled at least a part of the oil exporters (i.e. the competitive fringe) as price takers (cf. the excellent survey of Long, 2011).

We define $D_{t} \equiv p\left(S_{t}\right) S_{t}, t=1,2$, as the resource revenue accruing to the government in each period (ignoring for simplicity the fixed cost), where $p\left(S_{t}\right)$ denotes the inverse resource demand function. ${ }^{10}$

The probability $v$ of the government being victorious and hence holding on to office and not being removed by the rebels increases with the fighting effort by the government group $f_{G}$ and the quality of its army $\alpha$ but decreases with the fighting effort by the rebels $f_{R}$. Note that the quality of the rebel army is normalized to one and $\alpha$ indicates the superiority of the government weapon arsenal (hence we focus on $\alpha \geq 1$ ). We assume that if at least one faction selects positive fighting effort, i.e., $\max \left\{f_{G}, f_{R}\right\}>0$, the government's winning probability $v$ is given by the familiar ratio-form contest success function $v=\alpha f_{G} /\left(\alpha f_{G}+f_{R}\right)$ (cf., Tullock, 1980; Hirshleifer, 1991a,b; Skaperdas, 1996). Further, it is assumed that the government remains in power for sure, i.e. $v=1$, whenever both factions select zero fighting effort, i.e. $f_{G}=f_{R}=0$.

Total time available to both the government and rebel factions for either work or fighting is normalized to unity. The time that the government and rebel groups do not fight (i.e., $1-f_{G}$ and $1-f_{R}$, respectively), they work and earn an exogenous wage $W$. We do not include wage $W$ for period two, as this would be the same for all outcomes and therefore plays no role in the analysis. We could also allow for a psychic and casualty cost of war (e.g., $f_{G} \lambda$ and $f_{R} \lambda$, respectively), but analytically this is equivalent to increasing the wage with this cost of war (i.e., using $W+\lambda$ rather than $W$ as the wage). ${ }^{11}$

In addition to the rents from natural resource extraction, the group in power receives in each period additional "office rents" $B$ that are independent of natural resource extraction. In particular, there are two

\footnotetext{
${ }^{10}$ For technical reasons, we assume that the measuring unit of $S$ is scaled such that the price of the natural resource is always greater or equal to 1 (even if the whole resource was extracted in one period), i.e. $p(S) \geq 1$.

${ }^{11} \mathrm{We}$ abstract from the possibility that conflict adversely affects health and productivity of workers, destroys infrastructure, and thus lowers the wage (i.e., we ignore that $W$ may depend negatively on $f_{G}+f_{R}$ ).
} 
sources for these spoils of office: "ego rents" (cf., Rogoff, 1990), i.e. the psychological satisfaction from the honour of running the government, which do not create costs to anyone else; and bribes and other gains from corruption paid for by nationals and extracted from society at large. ${ }^{12}$ We assume that the government and rebels obtain the same rents from office $B$ in the event of controlling office. We also assume that $B$ is exogenous and does not entail any direct costs to other decision makers. One can think of $B$ being larger in countries that are autocratic and/or have high corruption levels.

Finally, we assume that governments and rebels are risk neutral and denote the discount rate by $\rho \geq 0$. The present value of the pay-offs to the government and rebel factions are thus given by:

$$
\begin{aligned}
& \Pi_{G}=B+p\left(S_{1}\right) S_{1}+\left(1-f_{G}\right) W+\frac{1}{1+\rho}\left[\left(\frac{\alpha f_{G}}{\alpha f_{G}+f_{R}}\right)\left(B+p\left(S_{2}\right) S_{2}\right)\right], \\
& \Pi_{R}=\left(1-f_{R}\right) W+\frac{1}{1+\rho}\left(\frac{f_{R}}{\alpha f_{G}+f_{R}}\right)\left(B+p\left(S_{2}\right) S_{2}\right) .
\end{aligned}
$$

The first two terms in the expression for the government faction payoff correspond to office rents plus oil revenues in period one, the third term is wage income earned when the government faction is not fighting, and the final term indicates the present value of expected future office rents and oil revenue. The payoff to the rebels is similar but without the first two terms.

We distinguish the cooperative and the non-cooperative outcome and indicate them by the superscripts $C$ and $N$, respectively. For the non-cooperative outcome, we assume that first the government decides how much to extract in period 1, then both factions decide on fighting levels, then the winner is announced and the new government is known, and finally the remaining reserves are extracted in period 2. Players solve the game by backward induction and take past costs and benefits as sunk.

\section{Rapacious Resource Extraction and Conflict}

Section 3.1 discusses the cooperative benchmark and section 3.2 the optimal extraction paths and fighting efforts in the non-cooperative outcome. Section 3.3 compares the two outcomes.

\subsection{Benchmark: Peace and the cooperative outcome}

The cooperative outcome maximizes the joint present value of the pay-offs

\footnotetext{
${ }^{12}$ The literature often focuses on these two sources of spoils of office (e.g., Osborne and Slivinski, 1996; Coate and Morris, 1999; and Eicher et al., 2009).
} 


$$
\Pi_{G}^{C}+\Pi_{R}^{C}=p\left(S_{1}\right) S_{1}+\left(2-f_{G}-f_{R}\right) W+\left(\frac{2+\rho}{1+\rho}\right) B+\left(\frac{1}{1+\rho}\right) p\left(S_{2}\right) S_{2}
$$

subject to the oil depletion equation (1). Clearly, there are only costs and no benefits to fighting, so that $f_{G}^{C}=f_{R}^{C}=0$. There is thus no war in the cooperative outcome. Substituting $S_{2}=S-S_{1}$ from (1) into (4) and maximizing with respect to $S_{1}$ yields the first-order condition:

$$
(1-1 / \varepsilon) p\left(S_{2}\right)=(1+\rho)(1-1 / \varepsilon) p\left(S_{1}\right) \Rightarrow S_{1}^{C}=\frac{(1+\rho)^{\varepsilon} S}{1+(1+\rho)^{\varepsilon}} \geq S_{2}^{C}=\frac{S}{1+(1+\rho)^{\varepsilon}}
$$

Equation (5) corresponds to the Hotelling principle which says that the rate of increase in the marginal revenue of the natural resource (or the resource price if the elasticity $\varepsilon$ is constant) must equal the market rate of interest for society to be indifferent between keeping the resource in situ and digging it up, selling it, and investing the proceeds. The resulting oil extraction path maximizes the present value of selling resource revenues to the world market. With a positive discount rate, this implies that current oil extraction is higher than future oil extraction. Note that for a zero discount rate, the Hotelling principle (5) says that the expected increase in the price of natural resources is zero in which case it pays to deplete each period an identical amount. ${ }^{13}$ This yields the convenient benchmark of balanced oil depletion:

$$
(1-1 / \varepsilon) p\left(S_{1}\right)=(1-1 / \varepsilon) p\left(S_{2}\right) \Rightarrow S_{1}^{C}=S_{2}^{C}=S / 2
$$

The joint pay-off in the cooperative outcome equals $\Pi_{G}^{C}+\Pi_{R}^{C}=\left(\frac{2+\rho}{1+\rho}\right) B+p\left(S_{1}^{C}\right) S_{1}^{C}+\frac{p\left(S_{2}^{C}\right) S_{2}^{C}}{1+\rho}+2 W$.

\subsection{The non-cooperative outcome: Fighting and rapacious resource exploitation}

The government decides on the oil extraction path. Since it decides on oil extraction in period 1, remaining reserves are extracted in period 2. Oil extraction in period 2 is thus given once the economy arrives in period 2 by untapped reserves (ignoring that oil reserves might be set on fire during conflict). Working backwards, the government and the rebels decide how much to fight given oil extraction in period 1. In the non-cooperative Nash equilibrium the government takes rebel fighting effort as given when maximizing its payoff and deciding on its fighting effort. This yields from (2) and (3) the following hump-shaped Nash reaction function:

\footnotetext{
${ }^{13}$ Of course, much of the cost of oil industries are lump sum (initial investments) whilst the marginal cost of pumping say oil out of the ground is small.
} 


$$
\frac{\partial \Pi_{G}}{\partial f_{G}}=\frac{\alpha f_{R}}{\left(\alpha f_{G}+f_{R}\right)^{2}}\left(\frac{B+p\left(S_{2}\right) S_{2}}{1+\rho}\right)-W=0 \Rightarrow f_{G}^{N}=\sqrt{\frac{f_{R}\left(B+p\left(S_{2}\right) S_{2}\right)}{\alpha W(1+\rho)}}-\frac{f_{R}}{\alpha} .
$$

Similarly, the rebels take government fighting effort as given when maximizing their payoff. This yields a similar hump-shaped reaction function for the rebels:

$$
\frac{\partial \Pi_{R}}{\partial f_{R}}=\frac{\alpha f_{G}}{\left(\alpha f_{G}+f_{R}\right)^{2}}\left(\frac{B+p\left(S_{2}\right) S_{2}}{1+\rho}\right)-W=0 \Rightarrow f_{R}^{N}=\sqrt{\frac{f_{G} \alpha\left(B+p\left(S_{2}\right) S_{2}\right)}{W(1+\rho)}}-\alpha f_{G} .
$$

The resulting Nash equilibrium in fighting efforts is obtained at the intersection of these two reaction functions (6) and (7) and is given by the symmetric outcome: ${ }^{14}$

$$
f_{G}^{N}=f_{R}^{N}=\frac{\alpha}{(1+\alpha)^{2}} \frac{B+p\left(S_{2}\right) S_{2}}{W(1+\rho)}>f_{G}^{C}=f_{R}^{C}=0 .
$$

Government and rebels fight more if the spoils from controlling the government, $B$, are high, expected resource revenues, $p\left(S_{2}\right) S_{2}$, are high, and return on work $W$ is low. Both government and rebels are deterred from fighting if the government has access to superior weapons. ${ }^{15}$ This result holds generally for standard ratio-form contest-success functions: higher asymmetry between fighting technologies of the conflict parties decreases total fighting efforts in equilibrium (Konrad, 2009). Another result is that fighting efforts are the same despite differences in weapon arsenal. Hence, the probability that the government remains in office in period 2 is simply an increasing function of its weapon arsenal:

$$
v^{N}=\alpha /(1+\alpha)
$$

Finally, the incumbent government in period 1 chooses oil extraction to maximize its payoff (2) subject to the fighting efforts (8) and the oil depletion constraint (1). The government thus chooses $S_{l}$ to maximize its reduced-form payoff:

$$
\Pi_{G}=\left(1+\frac{\alpha}{(1+\alpha)(1+\rho)}-\frac{\alpha}{(1+\alpha)^{2}(1+\rho)}\right) B+W+p\left(S_{1}\right) S_{1}+\left(\frac{\alpha}{1+\alpha}\right)^{2} \frac{p\left(S-S_{1}\right)\left(S-S_{1}\right)}{(1+\rho)} .
$$

This gives rise to the following inter-temporal efficiency condition:

\footnotetext{
${ }^{14}$ We suppose groups perfectly monitor each others' military strength. In a classic dynamic guns-versus-butter dilemma, not being able to monitor each others' military strength leads to a bigger build-up of armaments and lower social welfare (van der Ploeg and de Zeeuw, 1990).

${ }^{15}$ This follows from $\left(\partial\left[\alpha /(1+\alpha)^{2}\right] / \partial \alpha=-(\alpha-1) /(1+\alpha)^{3}<0\right.$ if $\alpha>1$.
} 


$$
(1+\rho)(1-1 / \varepsilon) p\left(S_{1}\right)=(1-1 / \varepsilon)\left(\frac{\alpha}{1+\alpha}\right)^{2} p\left(S_{2}\right) \Rightarrow S_{1}^{N}=\left(\frac{1+\alpha}{\alpha}\right)^{2 \varepsilon}(1+\rho)^{\varepsilon} S_{2}^{N}>S_{2}^{N}
$$

Hence, using the oil depletion constraint (1), we obtain current and future depletion:

$$
S_{1}^{N}=\frac{\left(\frac{1+\alpha}{\alpha}\right)^{2 \varepsilon}(1+\rho)^{\varepsilon}}{1+\left(\frac{1+\alpha}{\alpha}\right)^{2 \varepsilon}(1+\rho)^{\varepsilon}} S>S_{1}^{C} \geq \frac{1}{2} S \text { and } S_{2}^{N}=\frac{1}{1+\left(\frac{1+\alpha}{\alpha}\right)^{2 \varepsilon}(1+\rho)^{\varepsilon}} S<S_{2}^{C} \leq \frac{1}{2} S
$$

So conflict itself makes oil depletion rapacious. If the country has more monopoly power on the world resource market (lower $\varepsilon$ ), its incumbent government chooses to deplete reserves less vigorously in order not to forsake future oil rents. As a result, resource prices will be lower in the first period when more oil is pumped up than in the second period. If the government has lots of weapons at its disposal (large $\alpha$ ), its resource stakes are quite safe and thus the government can deplete its resource reserves less voraciously. Due to the specific functional form of the contest function, the speed of resource depletion does not depend on the opportunity cost of fighting $W$ or office rents $B$. In that sense, scarce resource rents are very different from office rents. Since rapacious resource depletion depresses future resource revenue, we see from (8) that this reduces the need to fight. Conflict about the spoils of future resource revenue thus leads to more rapacious resource depletion and thus to less fighting, but this conflict bias is attenuated if a lot of rent is at stake (i.e., if world resource demand is relatively inelastic).

\subsection{Comparing rapacious depletion under conflict with balanced depletion under peace}

Both balanced depletion under the cooperative outcome and rapacious depletion under the noncooperative outcome satisfy the Hotelling intertemporal arbitrage principle in the sense that the marginal revenue from oil in period 1 equals the expected marginal revenue from oil in period 2 . The difference between the non-cooperative and the cooperative outcome is that the former takes account of the possibility that the government may no longer be in office in period 2 (compare (11) with (5)) and therefore more of the oil revenue will appear in period 1 than in period 2 (see (12)). Since the inverse resource demand function is convex, this implies that the present value of oil revenue $D \equiv D_{1}+D_{2}$ under balanced depletion exceeds that under rapacious depletion:

$$
D^{C} \equiv p\left(S_{1}^{C}\right) S_{1}^{C}+p\left(S_{2}^{C}\right) S_{2}^{C}>p\left(S_{1}^{N}\right) S_{1}^{N}+p\left(S_{2}^{N}\right) S_{2}^{N} \equiv D^{N}
$$

Fighting and rapacious depletion that arise inexorably in the non-cooperative outcome thus depress total revenue from selling natural resources on the world market, i.e., $D^{N}<D^{C}$. Fig. 1 (a) sets $S=1$ and $\rho=0$ and shows total resource revenues as a function of the elasticity of world demand for the country's natural 
resources, $\varepsilon$. We see that a country with relatively inelastic demand for its resources has more monopoly power on the world resource market and gets more revenue. The dashed line indicates total resource revenue in the cooperative outcome with no fighting, $\mathrm{D}^{C}$; the solid line indicates total resource revenue in the non-cooperative outcome if the government has no weapon advantage, $\mathrm{D}^{N}(\alpha=1)$; and the dotted line indicates the same if the government does have a weapon advantage, $D^{N}(\alpha=2)$. The figure thus confirms that total resource revenue under the non-cooperative outcome is lower than that under the cooperative outcome, but less so if the government has a bigger weapon arsenal.

Figure 1: Non-cooperative and cooperative outcome under nationalized extraction as function of the elasticity of oil demand $\varepsilon$

(a) Total revenue $\left(p_{1} S_{1}+p_{2} S_{2}\right)$

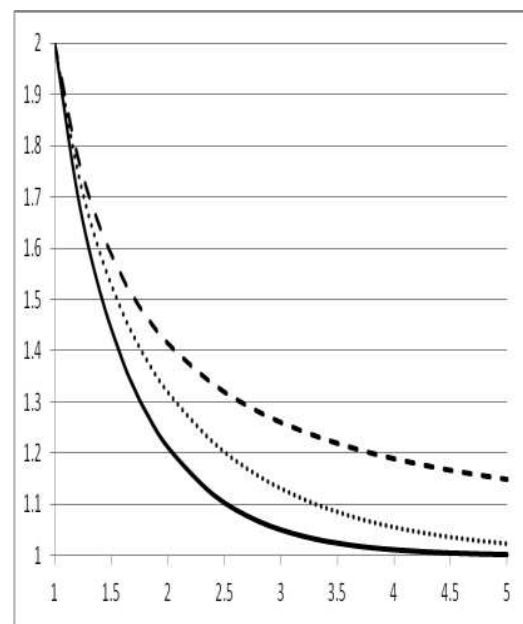

(b) Current extraction $\left(S_{1}\right)$

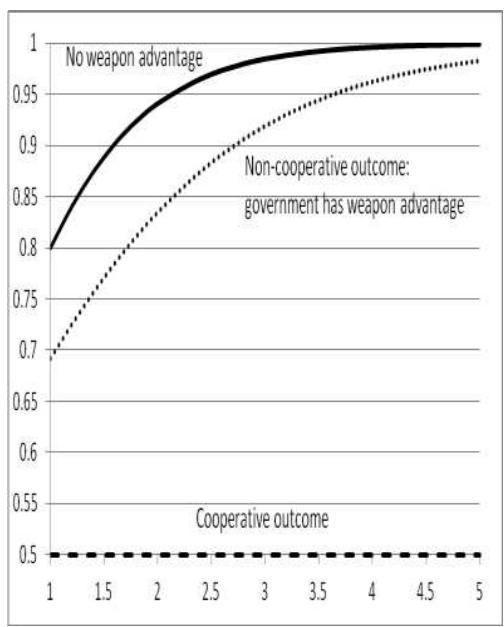

(c) Fighting efforts $\left(f_{G}=f_{R}\right)$

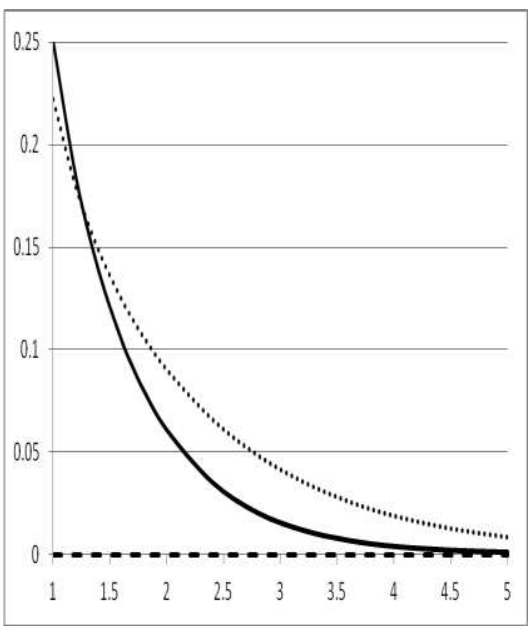

Fig. 1 (b) gives a similar picture for oil extraction in period 1. We see that oil extraction in the cooperative outcome is always balanced (i.e., half in each period) but oil extraction in the non-cooperative outcome is rapacious (i.e., more than half in period 1 and less than half in period 2). Oil extraction is less rapacious if the incumbent government stands to lose a lot of resource rents, i.e., if it has more monopoly power on the world resource market (lower $\varepsilon$ ) and if it has a more effective weapon arsenal at its disposal. Finally, fig. 1 (c) gives the corresponding picture for fighting efforts (setting $B=0$ and normalizing such that $W=$ 1 ). We see that a country with less monopoly power on the global resource market (higher $\varepsilon$ ) has less resource stakes and thus fights less. ${ }^{16}$ Indeed, as the country faces a more and more competitive resource market, fighting ceases altogether. As demand becomes more elastic extraction becomes more aggressive and thus future resource revenue and the stakes of the conflict diminish. This depresses fighting efforts.

\footnotetext{
${ }^{16}$ In a recent dynamic theory of inter-state resource wars the elasticity of oil demand is also a key parameter determining the incentives of war, since price taking firms fail to internalize the impact of extraction on military action (Acemoglu et al., 2012). Inelastic oil demand gives increasing war incentives over time, possibly making war inevitable.
} 
The effect of a bigger weapon arsenal on fighting efforts is more complicated. For low elasticities of resource demand, fighting efforts are less; for high elasticities, fighting intensifies with a bigger weapon arsenal. What is going on? An important reason for having more weapons is to stave off war. This is the

deterrence effect (i.e., the first term on the right-hand side of (8), $\frac{\alpha}{(1+\alpha)^{2}(1+\rho)}$, drops from 0.25 to 0.22 as $\alpha$ increases from 1 to 2). However, a bigger weapon arsenal also reduces the need for aggressive extraction so that future extraction and resource revenue are higher. This raises the stakes of the conflict and thus fighting is more intense. This is the stake effect (i.e., $p\left(S_{2}\right) S_{2}$ in the second term on the righthand side of (8) is higher if $\alpha$ is higher). The stake effect is larger for low elasticities of resource demand, since then more monopoly rents can be extracted from the sale of oil and thus the stake is higher. However, given convexity of demand, it follows that the effect of a bigger weapon arsenal on fighting efforts is ambiguous. For low elasticities of resource demand, the deterrence effect dominates so that the net effect of a bigger weapon arsenal is to curb fighting efforts. However, for high elasticities of world demand, the stake effect dominates and thus a bigger weapon arsenal increases fighting.

We summarize the results so far in the following proposition.

Proposition 1: Under nationalized resource extraction conflict about resource stakes makes natural resource extraction more rapacious, which depresses the present value of resource revenue, especially if world demand for natural resources is more elastic and the government's weapon arsenal is small. If demand is more elastic, there is less conflict. A bigger weapon arsenal deters rebels, which reduces fighting. More weaponry induces less aggressive extraction, which raises the stakes and increases fighting. The stake effect dominates the deterrence effect if resource demand is highly elastic.

Proof: Follows from equations (8), (12) and (13). Q.E.D.

Expression (8) indicates that government and rebels fight more vigorously if spoils of holding office are high and the return on working is low. Indeed, empirical evidence suggests that countries which are more corrupt and less democratic (i.e., with high $B$ ) and poor (i.e., low $W$ ) are more likely to experience civil war (e.g., Reynal-Querol, 2002; Fearon and Laitin, 2003; Collier and Hoeffler, 2004; Cederman and Girardin, 2007; Collier and Rohner, 2008; Collier et al., 2009). However, the speed of resource extraction is not affected by office rents or the wage. Expression (8) also indicates that fighting is more intense if expected future resource rents are high. Intuitively, rapacious depletion is less bellicose since factions are relatively more concerned with office rents as less natural resource revenues are left in the future. Balanced extraction induces more fighting and less productive activities. Fighting intensity is largest if 
fighting strengths are symmetric. The incumbent's chances of holding on to office are unaffected by the spoils of office or resource rents, but improve if it has better weaponry.

\section{Bribing Rebels ${ }^{17}$}

One way to avoid rebel coups is to offer rebels attractive jobs or to bribe them by supplementing wages. ${ }^{18}$ If the government offers a wage subsidy $\sigma$ to rebels only, the government payoff is reduced by $\left(1-f_{R}\right) \sigma$ and rebel wages are increased by the same amount. In terms of timing, first the government sets $\sigma$ and simultaneously selects $S_{l}$, and after that both factions choose their optimal fighting levels.

Proposition 2: It is optimal for government to pay rebels to work and put down their arms. The required wage subsidy is higher if oil and office rents are bigger. As a result, both rebels and government field a smaller army, but the rebels' army declines relatively more and thus the government's grip on office becomes stronger. Hence, oil depletion is less rapacious.

Proof: We solve the equilibrium backwards. The reaction functions of the government and rebels are as in (6) and (7), but rebels now have salary $W+\sigma$ rather than $W$. The intersection of these reaction functions yields the Nash Equilibrium. Thus, fighting efforts by government and rebels under the non-cooperative outcome with nationalized extraction are:

$$
f_{G}^{N}=\frac{\alpha(W+\sigma)}{[W+\alpha(W+\sigma)]^{2}}\left[B+p\left(S_{2}^{N}\right) S_{2}^{N}\right]>f_{R}^{N}=\frac{\alpha W}{[W+\alpha(W+\sigma)]^{2}}\left[B+p\left(S_{2}^{N}\right) S_{2}^{N}\right]>f_{G}^{C}=f_{R}^{C}=0 .
$$

Note that $\partial f_{G} / \partial \sigma<0, \partial f_{R} / \partial \sigma<0$. We also have:

$$
v^{N}=\frac{\alpha(W+\sigma)}{W+\alpha(W+\sigma)} \text { with } \partial v^{N} / \partial \sigma=\frac{\alpha W}{[W+\alpha(W+\sigma)]^{2}}>0
$$

The first order condition for the oil extraction decision yields,

$$
S_{1}^{N}=\frac{\left(\frac{W+\alpha(W+\sigma)}{\alpha(W+\sigma)}\right)^{2 \varepsilon}}{1+\left(\frac{W+\alpha(W+\sigma)}{\alpha(W+\sigma)}\right)^{2 \varepsilon}} S>\frac{1}{2} S \quad \text { and } \quad S_{2}^{N}=\frac{1}{1+\left(\frac{W+\alpha(W+\sigma)}{\alpha(W+\sigma)}\right)^{2 \varepsilon}} S<\frac{1}{2} S
$$

\footnotetext{
${ }^{17}$ From now on we assume for simplicity and without loss of generality that the interest and discount rates are zero. ${ }^{18}$ For wars between two rational and completely informed players it can be shown that, without binding contracts, war can be avoided if the "rich" player transfers parts of its money to the "poor" player (Beviá and Corchón, 2010).
} 
where $\partial S_{1}^{N} / \partial W>0, \partial S_{1}^{N} / \partial \sigma<0, \partial S_{1}^{N} / \partial \alpha<0, \partial S_{1}^{N} / \partial \varepsilon>0, \partial S_{1}^{N} / \partial S>0$ and thus $\partial S_{2}^{N} / \partial W<0, \partial S_{2}^{N} / \partial \sigma>0, \partial S_{2}^{N} / \partial \alpha>0, \partial S_{2}^{N} / \partial \varepsilon<0, \partial S_{2}^{N} / \partial S>0$,

while the optimality condition for the optimal wage subsidy yields:

$$
\sigma=\sqrt[3]{\frac{2(1+\alpha) W^{2}\left[B+p\left(S_{2}^{N}\right) S_{2}^{N}\right]}{\alpha^{2}}}-\frac{W(1+\alpha)}{\alpha},
$$

where $\partial \sigma / \partial B>0, \partial \sigma / \partial S_{2}^{N}>0$. The comparative statics results follow from the partial derivatives above. Q.E.D.

Bribes incite rebels to work rather than fight, hence they now fight less than the government. Still, there is fighting and in this sense bribing does not attain the peaceful outcome of the cooperative solution where the rebels are bribed. The probability of the government staying in office is higher if it introduces a wage subsidy for rebels. The optimal wage subsidy for rebels (15) sets the marginal benefit arising from a higher probability of staying in office ( $\partial v^{N} / \partial \sigma$ times the stake of future office and oil rents) equal to the marginal cost of the number of existing rebels plus the additional rebels who put down their arms who have to be subsidized to work, $\left(1-f_{R}^{N}-\sigma\left(\partial f_{R}^{N} / \partial \sigma\right)>1-f_{R}^{N}\right)$. It thus follows that a higher stake of oil or office rents warrants a bigger wage subsidy to incite rebels to fight less. The government incurs both the cost of fielding a bigger army and the cost of bribing rebels. Still, as the government's grip on office and on oil resources has tightened, it is more attractive for the government to deplete oil less rapaciously.

\section{Fighting and Exploitation Investment by Private Companies}

Instead of nationalized resource exploitation, the government might delegate this to a more efficient independent private company to encourage investment and exploration of new fields. Examples are the "Big Five" oil giants British Petroleum, Chevron, ConocoPhillips Company, ExxonMobil, and Royal Dutch Shell (Myers Jaffe and Soligo, 2007). The only assumptions that we make here are that this company is independent of the national government and that it is more efficient than a national state-run company. Hence, this definition could also include national private companies, or state-owned foreign companies, as long as they satisfy the two conditions of our assumption, namely that the exploitation company is independent of the national government and more efficient than a national state company.

The benefit of private oil companies is that they have the expertise and the cash to undertake investment $I$ to increase the supply of oil reserves: 


$$
S^{P}=(1+\Theta(I)) S \geq S, \quad \Theta(0)=0, \Theta^{\prime}>0, \Theta^{\prime \prime}<0,
$$

where $S^{P}$ denotes reserves under private exploitation. If the oil company gets the license to extract oil, it makes an oil field exploration investment and extracts zero oil in period 1 and $S^{P}$ units of oil in period 2. Total revenue for the oil company increases in initial known oil reserves $S$ and exploration investment $I$ :

$$
D^{P}(S, I)=p((1+\Theta(I)) S)(1+\Theta(I)) S, \quad D_{S}^{P}=(1+\Theta(I))\left(1-\frac{1}{\varepsilon}\right) p>0, D_{I}^{P}=\left(1-\frac{1}{\varepsilon}\right) p S \Theta^{\prime}>0
$$

The competitive license fee under privatized extraction will equal expected resource revenues minus the necessary investment outlay. The downside of this arrangement is that the government cannot guarantee to the oil company that it will stay in office, so that the company faces expropriation if rebels gain office. Before we discuss the implications of this downside, we briefly discuss as a benchmark what happens if government and rebels cooperate and there is no risk of expropriation. Afterwards, we analyze the noncooperative outcome. One way of interpreting our setup is that the government has access to alluvial natural resource deposits without having to invest in advanced exploitation technology whereas the private exploitation company has the knowledge and financial resources at its disposal to invest in exploitation technology to reach less easily accessible natural resource deposits. Hence, $I$ represents this additional exploration investment for gaining access to new oil reserves.

\subsection{Private extraction with credible commitment to peace}

If government and rebels cooperate, there is no need to fight. Hence, they maximize their joint payoff.

The payoff to rebels before compensation (3) is the wage, $\tilde{\Pi}_{R}^{N}=W$. The pay-off to the government (2) is $\tilde{\Pi}_{G}=W+2 B+L=W+2 B+D^{P}(S, I)-I$. The optimal investment by the oil company follows from setting the marginal revenue of oil to the marginal cost of finding an extra unit of oil reserves and increases with the initial stock of oil reserves:

$$
\left(1-\frac{1}{\varepsilon}\right) p((1+\Theta(I)) S) S \Theta^{\prime}(I)=1 \Rightarrow I^{P}=I^{C P}(\stackrel{+}{S}, \stackrel{+}{\varepsilon})>0, \quad S^{P}=S^{C P}(\stackrel{+}{S}, \stackrel{+}{\varepsilon})>S,
$$

where the superscript $C P$ denotes the cooperative outcome with private extraction. Investment and oil discoveries are higher if monopoly power of the oil producer is less (high $\varepsilon$ ). We assume that private extraction is the preferred mode under cooperation. Hence, revenue from competitively tendering off the oil license is higher than under cooperative and a fortiori non-cooperative nationalized extraction:

$$
L^{C P}(S)=D^{P}(S, I)-I>p(0.5 S) S>D_{1}^{N}+D_{2}^{N}, \quad L_{S}^{C P}=D_{S}^{C P}>0 .
$$


Since the government faction in each of the three extraction regimes gets office rents $B$ in each period and can under peace work undisturbed earning wage income $W$, the ranking of government payoffs under the peace outcome is the same. Since there is no fighting, peace is only sustained if the rebels receive side payments from the government (and implicitly from the private oil company). The magnitude of these side payments follow from the Nash bargaining solution, where the outcome depends on the fallback positions for both the government and the rebels. Such a cooperative outcome is only sustainable if the government credibly commits to pay the transfers and rebels credibly commit to renounce violence.

\subsection{Private extraction when government and rebels do not cooperate}

We now discuss situations where credible commitment to maintaining peace is infeasible. We assume the following timing: in period one, first, it is decided whether to engage in privatized extraction; second, if this is the case, there is an auction and license fees are paid by the highest bidder $^{19}$; third, the oil company incurs investment costs and at the same time both factions decide on fighting levels; and finally the new government is announced. In period two, if the government stays in power, the exploitation contract is honoured; if the rebels enter office, they expropriate the oil company. The government receives in period one office rent, license fee and wage income earned during the time that the government faction is not fighting and, if it stays in office, it receives in period two the expected spoils of office. If the rebels win they renege on the oil contract and thus receive in period two the expected value of office rents plus oil revenue. The assumption that the license fee is paid up-front eases exposition, but does not affect our results (see section 6 for what happens if part of the license fee is paid at the end of the period).

Our key assumption is that the government honours oil contracts and that these contracts are enforceable, i.e., it does not expropriate the oil company in the second period; rebels after victory do not respect past contracts and do expropriate the oil company. ${ }^{20}{ }^{21}$ Our results go through if the government is simply more likely than rebels to honour exploitation contracts. There is empirical evidence that indeed unconstitutional government change harms private investment (Le, 2004) and expropriations and nationalizations occur more often after regime change (Guriev et al., 2011; Albertus and Menaldo, $2010) .^{22}$

\footnotetext{
${ }^{19}$ We assume that oil companies do not have to pay any extra transfers to the government besides the license fee.

${ }^{20}$ If the government would also never honour oil exploration contracts, no private enterprise would ever want to do the initial investment and private extraction would not occur (which is not the case in reality).

${ }^{21}$ An alternative is that Nash bargaining takes place between the rebels and the oil company. Our main qualitative insights also hold for this alternative assumption.

${ }^{22}$ For illustration, many of the big expropriation and forced nationalization campaigns of the oil industry in the 1960s and 1970s took place shortly after coups and rebel victories, e.g. in Bangladesh, Bolivia, Ecuador, Ethiopia, Ghana, Iran, Iraq, Libya, Myanmar and Peru (cf. Guriev et al., 2011).
} 
We also assume that governments cannot credibly pre-commit ex-ante to how hard they will fight rebels in the future. The government thus faces a time inconsistency problem: it wants to credibly promise high future fighting efforts to obtain a larger license fee, but it has incentives to renege on this later on. This assumption is in line with the large empirical literature showing that governments are generally unable to commit to future fighting efforts (cf., Walter, 2009, for a survey).

Proposition 3: With privatized extraction and the government unable to commit to future fighting levels:

$$
f_{G}^{N P}=\frac{\alpha B^{2}}{\left[(1+\alpha) B+D^{N P}\right]^{2}} \frac{B+D^{N P}}{W}<f_{R}^{N P}=\frac{\alpha B\left(B+D^{N P}\right)}{\left[(1+\alpha) B+D^{N P}\right]^{2}} \frac{B+D^{N P}}{W},
$$

where $N P$ denotes the non-cooperative outcome with private extraction,

$$
v^{N P}=\frac{\alpha B}{(1+\alpha) B+D^{N P}}<v^{N}=\frac{\alpha}{1+\alpha}<v^{C}=1 .
$$

The exploitation company invests more, discovers more oil reserves, and pays a higher license fee if the government has superior weapons, office rents are large and oil demand is more elastic.

Proof: We solve this by backward induction, starting by computing the fighting efforts for a given level of $\Pi^{N P}$, and the optimal investment $I$ and hence $\Pi^{N P}$ for a given winning probability $v$. Payoffs to government and rebels are:

$$
\begin{aligned}
& \tilde{\Pi}_{G}^{P}=B+L^{N P}(S)+\left(\frac{\alpha f_{G}^{P}}{\alpha f_{G}^{P}+f_{R}^{P}}\right) B+\left(1-f_{G}^{P}\right) W, \\
& \tilde{\Pi}_{R}^{P}=\left(\frac{f_{R}^{P}}{\alpha f_{G}^{P}+f_{R}^{P}}\right)\left(B+D^{N P}\right)+\left(1-f_{R}^{P}\right) W,
\end{aligned}
$$

Given our timing assumptions, the government takes $L$ as sunk when deciding on its optimal fighting effort. This leads to the reaction function $f_{G}^{P}=\sqrt{\frac{f_{R}^{P} B}{\alpha W}}-\frac{f_{R}^{P}}{\alpha}$. The rebels maximize their payoff in (22) taking $f_{G}^{P}$ and future oil revenue $\Pi^{N P}$ as given, which yields the reaction function $f_{R}^{P}=\sqrt{\frac{f_{G}^{P} \alpha\left(B+D^{N P}\right)}{W}}-\alpha f_{G}^{P}$. The non-cooperative Nash equilibrium in fighting efforts is at the intersection of the two reaction functions and yields (20). Upon substitution of (20) into the contest success function, we obtain (21). Note that $\partial f_{R}^{P} / \partial D^{P}>0$. Further, $\partial f_{G}^{P} / \partial D^{P}<0$ if $D^{P}>(\alpha-1) B$. 
We can calculate the license fee, which now depends on the expected probability of keeping expected future oil revenue, i.e., $L=v p((1+\Theta(I)) S)(1+\Theta(I)) S-I$. Our timing assumptions imply that the oil company, when deciding how much to invest, takes $v$ as given. This yields the first order condition with respect to the optimal level of investment by the oil company:

$$
v\left(1-\frac{1}{\varepsilon}\right) p((1+\Theta(I)) S) S \Theta^{\prime}(I)=1 \Rightarrow I^{P}=I^{N P}\left(\stackrel{+}{S}, \stackrel{+}{\varepsilon}, v^{+}\right)<I^{C P}, \quad S<S^{P}=S^{N P}\left(\stackrel{+}{S}, \stackrel{+}{\varepsilon},,^{+}\right)<S^{C P} .
$$

The optimal level of investment, discovered oil reserves and license fee are higher if the probability that the incumbent hangs on to office $v$ is high. Given that we can see from (21) that $\partial v^{N P} / \partial B>0$ and $\partial v^{N P} / \partial \alpha>0$, we know from $\left(18^{\prime}\right)$ that $I^{P}=I^{N P}(\stackrel{+}{S}, \stackrel{+}{\varepsilon}, \stackrel{+}{B}, \stackrel{+}{\alpha})$. Further, we have that:

$$
L^{N P}(S, v)=v D^{N P}\left(S, I^{N P}\right)-I^{N P}, \quad L_{S}^{N P}=v D_{S}^{N P}>0, \quad L_{v}^{N P}=D^{N P}>0
$$

where $S^{P} \equiv S(1+\Theta(I))$, and oil revenue equals $D^{N P}\left(S, I^{N P}\right) \equiv p\left(S\left(1+\Theta\left(I^{N P}\right)\right) S\left(1+\Theta\left(I^{N P}\right)\right)<D^{C P}\right.$.

The participation constraint for the oil company implies $v^{P} D^{N P}=\left(\frac{\alpha f_{G}^{P}}{\alpha f_{G}^{P}+f_{R}^{P}}\right) D^{N P}=I^{N P}+L^{N P}$ under perfect competition. Using (20) and (21), we obtain:

$$
L^{N P}=\left[\frac{\alpha B}{(1+\alpha) B+D^{N P}}\right] D^{N P}-I^{N P}
$$

which increases in $\alpha$. Also, $\partial L / \partial D^{N P}=\alpha(1+\alpha) B^{2} /\left[(1+\alpha) B+D^{N P}\right]^{2}>0$ and

$$
\partial L / \partial B=\alpha D^{N P^{2}} /\left[(1+\alpha) B+D^{N P}\right]^{2}>0 \text {. Note that } \partial^{2} L / \partial^{2} B<0 \text { and } \partial^{2} L / \partial^{2} D^{N P}<0 . \quad \text { Q.E.D. }
$$

Hence, with privatized extraction and no government commitment to future fighting levels, rebels fight more and work less than the government. Furthermore, higher projected oil revenues induce rebels to fight more. Paradoxically, an increase in oil rents induces the government to fight less, as long as it does not have a big weapon advantage. After all, the stakes that matter for the government when deciding how big an army to field are merely the spoils of office. Rebels fight more and work less than the government faction, since they are not bound by the oil contract and grab all future oil revenue, so they are more likely to gain office. Hence, under private extraction the chances of the government staying in office are lower than under nationalized extraction. The participation constraint says that expected oil revenue must cover 
initial investment outlay plus the license fee. ${ }^{23}$ The license fee is higher if weapon technology of the government is better (higher $\alpha$ ), since then property rights of the government and thus of the oil exploration company are better protected. Further, the license fee increases in spoils of office $B$ and expected future resource revenues $D^{N P}$ and is curbed by the necessary exploitation investment outlays. All factors that favour military prospects of the government such as powerful weapons and large office rents result in better property rights protection and more exploration investment and a higher licence fee. Indeed, empirical evidence indicates that in politically unstable countries oil depletion paths are often suboptimal (Bohn and Deacon, 2000). Further, anecdotal evidence suggests that international oil companies offer "bad" exploitation deals to politically instable countries, and that in some instances these companies have engaged in direct military support of the government, for example by furnishing military equipment and weaponry; e.g., oil companies in Colombia, of Total in Burma or of Elf in Chad, Republic of Congo and Angola (Swanson, 2002; Humphreys, 2005). Our predictions are also backed up by systematic evidence from firm-level data indicating that governments in countries with higher democratic accountability, lower political risk and higher bureaucratic ability receive a larger share of oil rents while multinationals receive less (McMillan and Waxman, 2007).

An alternative assumption is that the government can pre-commit to fighting ahead and takes into account the positive effect of this on the license fee that can be obtained from the oil company. One can then show that there will be a symmetric outcome with more fighting, a bigger license fee, a higher probability of staying in office (even not taking account of oil revenue being larger) and a higher government payoff. Commitment is, however, hard to achieve in practice.

\subsection{Comparing the payoffs under nationalized and privatized extraction}

Substituting fighting efforts (8) into the payoff function (2) yields the non-cooperative Nash equilibrium payoffs for the government with nationalized extraction:

$$
\Pi_{G}^{N}=D_{1}^{N}+\frac{\alpha^{2}}{(1+\alpha)^{2}}\left(B+D_{2}^{N}\right)+B+W
$$

Making use of $\left(19^{\prime}\right),(20),(21)$ and (22), we write the corresponding payoff under private extraction as:

\footnotetext{
${ }^{23}$ Licenses can be allocated via a competitive auction (cf., Boadway and Keen, 2010, for an excellent survey on the closely related topic of taxation of natural resources). In general, a balance must be struck between efficient allocation of oil rights and high revenues for the government. A simultaneous first-price sealed-bid auction may suffice when competition is weak and values are additive; with more complex value structures dynamic auctions with package bids such as the clock-proxy auction are preferable (Cramton, 2007).
} 


$$
\Pi_{G}^{N P}=L^{N P}\left(S, \frac{\alpha B}{(1+\alpha) B+D^{N P}}\right)+\left(\frac{\alpha}{1+\alpha+D^{N P} / B}\right)^{2} B+B+W
$$

If credible commitment is infeasible and government and rebels do not cooperate, it follows from comparing (25) and (24) that the government prefers extraction by the private oil company, $\Pi_{G}^{N P}>\Pi_{G}^{N}$, if:

$$
L^{N P}\left(S, \frac{\alpha B}{(1+\alpha) B+D^{N P}}\right)-\left(D_{1}^{N}+\frac{\alpha^{2}}{(1+\alpha)^{2}} D_{2}^{N}\right)>\frac{\alpha^{2}}{(1+\alpha)^{2}} B-\left(\frac{\alpha}{1+\alpha+D^{N P} / B}\right)^{2} B>0
$$

On the one hand, private extraction permits more investment, oil discoveries and potentially more oil revenue (efficiency gains). On the other hand, as revenue is not up-front, conflict is more intensive, the prospects of government holding on to office and protecting the oil company are slimmer and investment by the oil company will be deterred (holdup problem). The government prefers extraction by the private oil company if the efficiency gains $\left(L^{N P}(S)-D_{1}^{N}-\frac{\alpha^{2}}{(1+\alpha)} D_{2}^{N}\right)$ exceed the losses from more rapacious extraction and the holdup problem. We also see from (26) that private extraction is preferred by the government if its weapon strength $(\alpha)$ and spoils from office $(B)$ are large enough as both of these reduce the holdup problem. Higher office rents thus favor the government selecting more efficient privatized oil extraction, so we expect spoils of office and oil output to be positively correlated. Since corruption increases office rents, this corroborates evidence that suggests that oil production is associated with more corruption (Isham et al., 2005). The positive correlation between oil and corruption only holds for undemocratic countries where it may be harder to achieve the cooperative outcome in our setting (Bhattacharyya and Hodler, 2010). While the prevailing literature focuses on natural resources destroying good governance in rentier states, we argue that there also is another channel with the opposite direction of causality. Undemocratic and corrupt regimes find it easier to commit to putting down rebels as the stakes of office are very high. These incentives for intense government fighting lead to better protection of property rights for private companies and thus encourage investment and extraction.

In a nutshell, if credible commitments to peace and side payments are feasible, cooperation sustains peace with extraction delegated to a more efficient private oil company and rebels receiving a share of oil rents. Without credible commitment and side payments, fighting will occur. This is in line with empirical evidence that shows that the resource curse can be turned into a blessing in countries with good institutions (Mehlum et al., 2006). Indeed, social tensions and distributive conflict are less salient if consensual political institutions and power-sharing are in place (Reynal-Querol, 2002; Cederman and Girardin, 2007). Empirical evidence suggests that democracies opt less frequently for (nationalized) 
rapacious depletion (Le and Reuveny, 2006) and nationalization of oil companies occurs more often if the quality of institutions is low (Guriev, et al., 2011).

\section{More complex oil contracts}

In practice there are many types of more complex contracts. For example, only part $(1-z)$ of the license fee $L$ may be paid up-front and part $z$ received after oil extraction has taken place and the government has not been removed from office. So, the government only gets control of the part $z$ of the license fee if it holds onto office. Assuming that the contract, and in particular $z$ and $L$, is negotiated before fighting takes place and the government cannot pre-commit, we derive the following proposition.

Proposition 4: Holding future oil revenue constant, paying less of the license fee upfront (higher z) implies that the government fields a bigger army and the rebels a smaller one whilst the government improves its chances of staying in power. However, this is partly offset by a countervailing effect, as paying less upfront implies that the oil company invests more and future oil revenue is higher which stimulates conflict and reduces chances of staying in power. This latter effect is strong if oil demand is less elastic (Elower).

Proof: The payoffs to the government and rebels are:

$$
\begin{aligned}
& \Pi_{G}^{P A}=B+(1-z) L^{P A}+\left(\frac{\alpha f_{G}^{P A}}{\alpha f_{G}^{P A}+f_{R}^{P A}}\right)\left(B+z L^{P A}\right)+\left(1-f_{G}^{P A}\right) W, \\
& \Pi_{R}^{P A}=\left(\frac{f_{R}^{P A}}{\alpha f_{G}^{P A}+f_{R}^{P A}}\right)\left(B+D^{P A}\right)+\left(1-f_{R}^{P A}\right) W
\end{aligned}
$$

where the outcome with only part of the fee paid upfront is denoted by the superscript $P A$. The government treats $(1-z) L^{P A}$ as sunk. Maximizing these pay-offs taking rival fighting as given yields the non-cooperative Nash equilibrium:

$$
\begin{aligned}
& f_{G}^{P A}=\frac{\alpha\left(B+D^{P A}\right)\left(B+z L^{P A}\right)^{2}}{\left[(1+\alpha) B+D^{P A}+\alpha z L^{P A}\right]^{2} W}<f_{R}^{P A}=\frac{\alpha\left(B+D^{P A}\right)^{2}\left(B+z L^{P A}\right)}{\left[(1+\alpha) B+D^{P A}+\alpha z L^{P A}\right]^{2} W}, \\
& f_{G}^{P A}+f_{R}^{P A}=\frac{\alpha\left(B+D^{P A}\right)}{W} \frac{\left(B+z L^{P A}\right)\left(2 B+D^{P A}+z L^{P A}\right)}{\left[(1+\alpha) B+D^{P A}+\alpha z L^{P A}\right]^{2}} .
\end{aligned}
$$

Substituting (28) into the contest success function, we obtain:

$$
v^{P A}=\frac{\alpha\left(B+z L^{P A}\right)}{\alpha\left(B+z L^{P A}\right)+B+D^{P A}}<v^{N}=\frac{\alpha}{1+\alpha} .
$$


We immediately see from (28) and (29) that $\partial f_{G}^{P A} / \partial\left({ }_{z} L^{P A}\right)>0$ and $\partial v^{P A} / \partial\left(z L^{P A}\right)>0$. Comparing (29) with (21), we thus see that $v^{P A}>v^{N P}$ on the assumption that $D^{P A}=D^{N P}$. Further, given that

$$
\begin{aligned}
& (1-z) L^{P A}+v z L^{P A}=v D^{N P}\left(I^{N P}\right)-I^{N P} \text { we have: }{ }^{24} \\
& v\left(1-\frac{1}{\varepsilon}\right) p((1+\Theta(I)) S) S \Theta^{\prime}(I)=1 \\
& \left(18^{\prime \prime}\right) \quad \Rightarrow\left[\frac{\alpha\left(B+z L^{P A}\right)}{\alpha\left(B+z L^{P A}\right)+B+D^{P A}}\right]\left(1-\frac{1}{\varepsilon}\right) p((1+\Theta(I)) S) S \Theta^{\prime}(I)=1 \\
& \Rightarrow \quad I^{P A}\left(\stackrel{+}{S}, \begin{array}{c}
+ \\
\varepsilon, v, z
\end{array}\right)<I^{C P} .
\end{aligned}
$$

It can be shown that $I^{P A}>I^{N P}$ and $D^{P A}>D^{N P}$ for $z>0$. This pushes down $v^{P A}$ and thus partly offsets the gap between $v^{P A}$ and $v^{N P}$. Further, it can be shown that $\partial^{2} I^{P A} / \partial z \partial \varepsilon<0$, so that this second effect is stronger if $\varepsilon$ is low. Q.E.D.

There are two effects at play. First, if some of the license fee is paid after the extraction takes place, the government has more at stake $\mathrm{s}^{25}$ and thus fields a bigger army and raises its chances of staying in office. Second, if less has to be paid up-front, the oil company invests more and thus future oil stakes are higher. This partly offsets the reduction in conflict and lessens the hold on office by the incumbent. The more monopoly power the oil company has on the world market (lower $\varepsilon$ ), the more attractive it is to invest more if it has to pay less upfront.

Of course, in practice oil contracts contain many more details and relate very closely to how royalties, taxes, production sharing agreements, joint ventures and service agreements affect the government take (see Johnston (2007) and Daniel et al. (2010) for useful overviews of the issues). Thought needs to go into designing the best way to auction oil rights; if competition is weak and value structures are not too complex, a competitive first-price sealed-bid auction may suffice and else a dynamic auction with package bids such as the clock-proxy auction may be needed (e.g., Cramton, 2007). Applications of modern contract theory have emphasized the role of asymmetric information, adverse selection and the need to specify special provisions about risk sharing (Leland, 1976; Hung et al., 2006). Rather than having an ex post windfall tax when oil prices double, the contract may specify ex ante the government

\footnotetext{
${ }^{24}$ The license fee is paid upfront and is also stipulated in a contract, so is a sunk cost.

${ }^{25}$ Since the oil company's participation constraint, $v^{P A}\left(D^{P A}-z L\right) \geq(1-z) L+I$, binds under perfect competition, we get the following expression for the future stake: $B+z L=B+z\left(v^{P A} D^{P A}-I\right) /\left(1-z\left(1-v^{P A}\right)\right)$.
} 
shares in the supernumerary profits in order to avoid holdup problems in exploitation investment (Engel and Fischer, 2010). It is beyond our scope to model these contract intricacies in detail.

\section{Conclusions}

We have presented a framework that makes both conflict behaviour and oil extraction endogenous. With a small number of exogenous parameters related to extraction technology and spoils of office, we derive a multitude of predictions on conflict variables such as the equilibrium fighting efforts, variables related to oil depletion like extraction method, extraction speed, exploration investment and licence fees, and political outcomes like regime durability.

The looming shadow of conflict results in imperfect property rights protection and policies have to take account of this primary distortion. With a nationalized oil industry, extraction will be rapacious if government and rebels do not cooperate. This depresses the present value of oil revenue, especially if world oil demand is more elastic and the government's weapon arsenal is small. As far as political turmoil is concerned, a more elastic demand and a bigger weapon arsenal of the government deter rebels, which reduces fighting. But there is also a countervailing effect of heavier weaponry, as it induces less aggressive extraction, which raises the stakes and increases fighting. The stake effect dominates the deterrence effect if resource demand is highly elastic. We have also shown that it is optimal for the government to bribe rebels to encourage them to work and put their arms down and that this wage subsidy is higher if oil and office rents are bigger. As a result, both rebels and government field a smaller army, but the rebels' army declines relatively more and thus the government's grip on office becomes stronger. Hence, oil depletion is less rapacious.

While private extraction would be most efficient on purely economic grounds, the holdup problem on the oil company's investment implies that private extraction is only attractive if the threat from rebels is not too large (i.e., with large office rents and a strong army), as fragile governments can only gain modest incentive compatible license fees, and political instability reduces private investment levels. In fact, with privatized extraction and the government unable to commit to future fighting levels, the government fights less intensively than the rebels and its chance of staying in office are less than under nationalized oil extraction. It thus follows that government turnover is higher under private extraction. The government's grip on power also affects oil exploration: the oil exploitation company invests more, discovers more oil reserves, and pays a higher license fee if the government has superior weapons, office rents are large (which both reduce government turnover), and also if oil demand is more elastic. 
As discussed earlier, one of the reasons why property rights of private extraction investments are poorly protected is the fact that the government treats received licence fees as sunk and has incentives to select "too low" fighting efforts in the future. There are several ways in which the government can try to overcome this time inconsistency problem. First, "back-loaded" oil contracts that stipulate the payment of a large part of the licence fee ex post keep the government's fighting incentives high. Holding future oil revenue constant, paying less of the license fee upfront indeed implies that the government fields a bigger army and the rebels a smaller one whilst the government improves its chances of staying in power. However, this effect is partly offset by a countervailing force, as paying less upfront implies that the oil company invests more and future oil revenue is higher which stimulates conflict and reduces chances of staying in power. This latter effect is strong if oil demand is less elastic.

Second, if feasible, the government's commitment to future weapon investments before oil licenses are sold can help to overcome the time inconsistency problem. Let us sketch in some detail what would happen in our model if we allowed for endogenous weaponry investment. If the government cannot precommit to invest in weaponry and to fighting efforts before licenses are auctioned, the license fee is a bygone at the moment when decisions are made about fighting efforts and weapon investments, and hence the stake is $B$ and not $B+L$. It follows that the optimal investment in weapons increases in oil plus office rents, but decreases in the ratio of oil to office rents. The government invests less in weaponry if it cannot commit itself to investing in weaponry and fighting efforts, and thus to safeguarding property rights on natural resources. Not being able to commit to investment in weaponry and fighting efforts means that oil rights are less protected and thus that the government obtains a lower license fee than if it can commit. The incumbent faces a time inconsistency problem: it wants to convince the oil company that it will invest a lot in weapons to stave off rebellion and make oil investments attractive, but once the license fee has been received it has an incentive to renege. Without commitment, investment in weaponry is too low and both the government and the oil company are worse off as a result. In contrast, if the government is able to commit to future weaponry investments, it offers more secure oil rights and thus extracts a bigger fee from the oil company. This way the government also increases its grip on office. ${ }^{26}$

Our analysis highlights the importance of explaining conflict and resource extraction simultaneously in empirical work; existing estimates of the effect of resources on conflict may suffer from endogeneity bias. Some of our results with respect to the determinants of fighting or with respect to factors favouring underinvestment can provide mechanisms to explain existing empirical results, as discussed above. In contrast,

${ }^{26}$ Empirically, oil increases the risk of conflict in non-corrupt countries, but in corrupt countries it has a less detrimental effect on stability (Fjelde, 2009). This and the positive relation between corruption and military spending found by Gupta et al. (2001) are consistent with the idea that high spoils of office induce large army investments by the government and diminish the effects of resources on conflict. 
other propositions require new empirical efforts. For example, the expected effects of domestic political institutions and military capacity on the ownership structure and depletion speed of extraction companies, as well as on the share of rents captured by the government through licence fees, are still largely empirical terra incognita. Similarly, our prediction of a "conditional resource curse", making the conflict inducing impact of natural resources depend on extraction method and speed, as well as on military asymmetry, needs further empirical investigation. Moreover, our findings on the impact of speed and method of extraction on government turnover and army size suggest new topics for empirical testing.

Our theoretical analysis can also be extended in the following directions. First, if the government has cash constraints and cannot use future resource revenue as collateral, private oil companies have an incentive to finance an army to fight off rebel coups. These constraints bias the mode of exploration towards more rapacious nationalized or privatized extraction, as this yields more funds upfront to bribe rebels, field a bigger army and have more advanced weaponry. However, looting and "booty futures" can also finance a stronger rebel army which can set off or prolong conflict (Ross, 2004). Second, oil companies may not have an interest to disclose private information about in-situ reserves, necessary investment outlays, or costs of extraction to the government, in which case the design of incentive-compatible contracts under moral hazard with risk sharing is called for (e.g., Bolton and Dewatripont, 2005; Radon, 2007). Third, with capital-intensive extraction companies (say, oil or gas) a higher price of resources pushes up the relative return on capital and pushes down the wage, which boosts conflict (Dal Bó and Dal Bó, 2011). With less rapacious depletion, fighting intensities increase more, as not only the wage falls, but also the revenues from natural resources and thus the stakes rise. On the other hand, a higher price of labourintensive resources (e.g., coffee, rice or bananas) pushes up wages and reduces the return on capital, so fighting becomes less intense and work more attractive, which could make balanced resource extraction relatively more attractive. Fourth, we find that fast depletion of natural resources occurs due to insecure control over future ownership of the resource and the consequent threat of expropriation, but too slow depletion may occur due to the holdup problem and the resulting lack of investment in oil exploration (cf., Bohn and Deacon, 2000). Although some work has been done with an exogenous expected chance of expropriation and an exogenous confiscation risk (Strand, 2010), more work is needed to make both these effects endogenous. Of course, vertical integration or nationalization can solve the holdup problem. Finally, aggressive extraction resulting from the threat of expropriation may be less severe with rival oil companies that face a future threat of expropriation. Oil companies are then induced to conserve oil in order to have less competition in the future if rivals get expropriated (Laurent-Luchetti and Santaguni, 2012). 


\section{Acknowledgement}

We thank the editor, Theo Eicher, and two anonymous referees for very helpful comments. In particular, we are grateful for them insisting to make the speed of resource depletion endogenous. Further, we are grateful to Erwin Bulte, Solomon Polachek and participants of the OxCarre-DSG conference, December 2009, Dubai and the ASSA/AEA meeting, January 2010, Atlanta for helpful comments on an earlier version. The support from the BP financed Oxford Centre for Analysis of Resource Rich Economies is gratefully acknowledged. Dominic Rohner gratefully acknowledges financial support from the Swiss National Science Foundation Grant no. 100014-122636.

\section{References}

Acemoglu, D., Golosov, M., Tsyvinski, A., Yared, P., 2012. A dynamic theory of resource wars, Quarterly Journal of Economics, 127: 283-331.

Albertus, M., Menaldo, V., 2010. If you're against them you're with us: the effect of expropriation on autocratic survival, Comparative Political Studies, forthcoming.

Al-Obaidan, A., Scully, G.,1991. Efficiency differences between private and state-owned enterprises in the international petroleum industry, Applied Economics, 23: 237-46.

Andersen, J.J., Aslaksen, S., 2011. Oil and political survival, mimeo., University of Oslo.

Angrist, J., Kugler, A., 2008. Rural windfall or a new resource curse? Coca, income, and civil conflict in Colombia, Review of Economics and Statistics, 90: 191-215.

Baik, K., Shogren, J., 1992. Strategic behavior in contests: comment”, American Economic Review, 82: 359-362.

Besley, T.J., Persson, T., 2011. The logic of political violence, Quarterly Journal of Economics, 126: 1411-1445.

Beviá, C., Corchón, L.C., 2010. Peace agreements without commitment, Games and Economic Behavior, 68: 469-487.

Bhattacharyya, S., Hodler, R., 2010. Natural resources, democracy and corruption, European Economic Review, 54: 608-21.

Boadway, R., Keen, M., 2010. Theoretical perspectives on resource tax design, in: Daniel, Ph., Keen, M., McPherson, Ch. (eds.), The Taxation of Petroleum and Minerals: Principles, Problems and Practice, Routledge, Abingdon UK.

Bohn, H., Deacon, R., 2000. Ownership risk, investment, and the use of natural resources, American Economic Review, 90: 526-49.

Bolton, P., Dewatripont, M., 2005. Contract Theory, Cambridge, Ma.: MIT Press.

Brückner, M., Ciccone, A., 2010. International commodity prices, growth, and the outbreak of civil war in Sub-Saharan Africa, Economic Journal, 120: 519-34.

Caselli, F., Morelli, M., Rohner, D., 2011. The geography of inter-state resource wars", mimeo, LSE, Columbia University, and University of Zurich.

Cederman, L.-E., Girardin, L., 2007. Beyond fractionalization: mapping ethnicity onto nationalist insurgencies, American Political Science Review, 101: 173-85.

Cherian, J.A., E. Perotti, E., 2001, Option pricing and foreign investment under political risk, Journal of International Economics, 55: 359-377.

Coate, S., Morris, S., 1999. Policy persistence, American Economic Review, 89: 1327-1336.

Collier, P., Hoeffler, A., 2004. Greed and grievance in civil war, Oxford Economic Papers, 56: 563-95. 
Collier, P., Hoeffler, A., Rohner, D., 2009. Beyond greed and grievance: feasibility and civil war, Oxford Economic Papers, 61: 1-27.

Collier, P., Rohner, D., 2008. Democracy, development, and conflict, Journal of the European Economic Association, 6: 531-40.

Cooper, J.C.B., 2003. Price elasticity of demand for crude oil: estimates for 23 countries, OPEC Review, 27: $1-8$.

Cramton, P., 2007. How best to auction oil rights, in M. Humphreys, J.D. Sachs and J.E. Stiglitz (eds.), Escaping the Resource Curse, New York: Columbia University Press, pp. 114-151.

Dal Bó, E., Dal Bó, P., 2011. Workers, warriors, and criminals: social conflict in general equilibrium, Journal of the European Economic Association, 9: 646-677.

Daniel, Ph., Keen, M., McPherson, Ch. (eds.), 2010. The Taxation of Petroleum and Minerals: Principles, Problems and Practice, Routledge, Abingdon UK.

Deacon, R., 1999. Deforestation and ownership: evidence from historical accounts and contemporary data, Land Economics, 71: 526-49.

Deacon, R., Mueller, B., 2006. Political economy and natural resource use, in R. Lopez and M. Toman (eds.), Economic Development and Environmental Sustainability: New Policy Options, Oxford: Oxford University Press, pp. 122-53.

De Soysa, I., 2002. Paradise is a bazaar? Greed, creed and governance in civil war, 1989-99, Journal of Peace Research, 39: 395-416.

Dixit, A., 1987. Strategic behavior in contests, American Economic Review, 77: 891-898.

Dube, O., Vargas, J., 2011. Commodity price shocks and civil conflict: evidence from Colombia, mimeo, NYU and Universidad del Rosario.

Eicher, T., Garcia-Penalosa, C., and van Ypersele, T., 2009. Education, corruption, and the distribution of income, Journal of Economic Growth, 14: 205-231.

Eller, S., Hartley, P., Medlock, K., 2011. Empirical evidence on the operational efficiency of national oil companies, Empirical Economics, 40: 623-643.

Engel, E., Fischer, R., 2010. Optimal resource extraction contracts under threat of expropriation, in W. Hogan and F. Sturzenegger (eds.), The Natural Resource Trap, Cambridge MA: MIT Press.

Esteban, J., Morelli, M., Rohner, D., 2011, Strategic mass killings, mimeo, IAE Barcelona, Columbia University, and University of Zurich.

Fearon, J., Laitin, D., 2003. Ethnicity, insurgency, and civil war, American Political Science Review, 97: 75-90.

Fearon, J., 2004. Why do some civil wars last so much longer than others?, Journal of Peace Research, 41: 275-301.

Fearon, J., 2005. Primary commodity exports and civil war, Journal of Conflict Resolution, 49: 483-507.

Fjelde, H., 2009. Buying peace? Oil wealth, corruption and civil war, 1985-99, Journal of Peace Research, 46: 199-218.

Gonzalez, F., 2005. Insecure property and technological backwardness, Economic Journal, 115: 703-21.

Grossman, H., Mendoza, J., 2003. Scarcity and appropriative competition, European Journal of Political Economy, 19: 747-58.

Gupta, S., de Mello, L., Sharan, R., 2001. Corruption and military spending, European Journal of Political Economy, 17: 749-77.

Guriev, S., Kolotilin, A., Sonin, K., 2011. Determinants of nationalization in the oil sector: a theory and evidence from panel data, Journal of Law, Economics and Organization, 27: 301-323.

Hirshleifer, J., 1991a. The technology of conflict as an economic activity, American Economic Review, 81: 130-134. 
Hirshleifer, J., 1991b. The paradox of power, Economics and Politics, 3: 177-200.

Hodler, R., 2006. The curse of natural resources in fractionalized countries, European Economic Review, 50: $1367-86$.

Hotte, L., 2001. Conflicts over property rights and natural-resource exploitation at the frontier, Journal of Development Economics, 66: 1-21.

Hotte, L., 2005. Natural-resource exploitation with costly enforcement of property rights, Oxford Economic Papers, 57: 497-521.

Humphreys, M., 2005. Natural resources, conflict, and conflict resolution: uncovering the mechanisms, Journal of Conflict Resolution, 49: 508-37.

Hung, N.M., Poudo, J.-C., Thomas, L., 2006. Optimal resource extraction contract with adverse selection, Resources Policy, 31: 78-85.

Hurley, T.M., Shogren, J.M., 1998. Effort levels in a Cournot Nash contest with asymmetric information, Journal of Public Economics, 69: 195-210.

Isham, J., Woolcock, M., Pritchett, L., Busby, G., 2005. The varieties of resource experience: natural resource export structures and the political economy of economic growth, World Bank Economic Review, 19: 141-74.

Janus, T., 2012. Natural resource extraction and civil conflict, Journal of Development Economics, 97: 24-31.

Johnston, D., 2007. How to evaluate the fiscal terms of oil contracts, in M. Humphreys, J.D. Sachs and J.E. Stiglitz (eds.), Escaping the Resource Curse, New York: Columbia University Press, pp. 114151.

Konrad, K., 2009. Strategy and Dynamics in Contests, Oxford: Oxford University Press.

Konrad, K., Olsen, T.E., and Schöb, R., 1994. Resource extraction and the threat of possible expropriation: the role of Swiss bank accounts, Journal of Environmental Economics and Management, 26: 149-162.

Le, Q., 2004. Political and economic determinants of private investment, Journal of International Development, 16: 589-604.

Le, Q., Reuveny, R., 2006. Democracy and environmental degradation, International Studies Quarterly, 50: 935-56.

Leland, H.E., 1976. Optimal risk sharing and the leasing of natural resources, with applications to oil and gas leasing on the Ocs, Quarterly Journal of Economics, 92: 413-438.

Long, N. Van, 1975. Resource extraction under the uncertainty about possible nationalization, Journal of Economic Theory, 10: 42-53.

Long, N. Van, 2011. Dynamic games in the economics of natural resources: a survey, Dynamic Games and Applications, 1: 115-148.

Laurent-Luchetti, J. and Santuguni, M. 2012. Ownership risk and the use of common-pool natural resources, Journal of Environmental Economics and Management, 63: 242-259.

Lujala, P., Gleditsch, N.P., Gilmore, E., 2005. A diamond curse? Civil war and a lootable resource, Journal of Conflict Resolution, 49: 538-62.

Lujala, P., 2009. Deadly combat over natural resources: gems, petroleum, drugs, and the severity of armed civil conflict, Journal of Conflict Resolution, 53: 50-71.

Lujala, P., 2010. The spoils of nature: armed civil conflict and rebel access to natural resources, Journal of Peace Research, 47: 15-28.

Maxwell, J., Reuveny, R., 2005. Continuing conflict, Journal of Economic Behavior and Organization, 58: $30-52$. 
McMillan, M., Waxman, A., 2007. Profit sharing between governments and multinationals in natural resource extraction: evidence from a firm-level panel, Brookings Trade Forum, 149-175.

Mehlum, H., Moene,K., Torvik, R., 2006. Institutions and the resource curse, Economic Journal, 116: 120.

Morelli, M., Rohner, D., 2011. Natural resource distribution and multiple forms of civil war, mimeo, Columbia University and University of Zurich.

Myers Jaffe, A., Soligo, R., 2007. The international oil companies, mimeo, James A. Baker III Institute. Olsson, O., Fors, H.C., 2004. Congo: the prize of predation, Journal of Peace Research, 41: 321-36.

Osborne, M., Slivinski, A., 1996. A model of political competition with citizen-candidates, 111: 65-96.

Ploeg, F. van der, 2010. Voracious transformation of a common natural resource into productive capital, International Economic Review, 51, 2: 365-381.

Ploeg, F. van der, Zeeuw, A.J. de, 1990. Perfect equilibrium in a model competitive arms accumulation, International Economic Review, 31: 131-46.

Radon, J., 2007. How to negotiate an oil contract, in M. Humphreys, J.D. Sachs and J.E. Stiglitz (eds.), Escaping the Resource Curse, New York: Columbia University Press, pp. 89-113.

Reynal-Querol, M., 2002. Ethnicity, political systems, and civil wars, Journal of Conflict Resolution, 46: 29-54.

Robinson, J., Torvik, R., Verdier, T., 2006. Political foundations of the resource curse, Journal of Development Economics, 79: 447-68.

Rohner, D., 2006. Beach holiday in Bali or East-Timor? Why conflict can lead to under- and overexploitation of natural resources, Economics Letters, 92: 113-7.

Rohner, D., 2011. Reputation, group structure and social tensions, Journal of Development Economics, 96: 188-199.

Rogoff, K., 1990. Equilibrium political budget cycles, American Economic Review, 80: 21-36.

Ross, M., 2004. What do we know about natural resources and civil war?, Journal of Peace Research, 41: 337-56.

Ross, M., 2006. A closer look at oil, diamonds, and civil war, Annual Review of Political Science, 9: 265300 .

Sinn, H.-W., 1984. Common property resources, storage facilities and ownership structures: a Cournot model of the oil market, Economica, 51: 235-252.

Skaperdas, S., 1992. Cooperation, conflict, and power in the absence of property rights, American Economic Review, 82: 720-739.

Skaperdas, S., 1996, Contest success functions, Economic Theory, 7: 283-290.

Strand, J., 2010. Optimal fossil-fuel taxation with backstop technologies and tenure risk, Energy Economics, 32: 418-422.

Swanson, P., 2002. Fuelling conflict: the oil industry and armed conflict, mimeo, Fafo.

Tornell, A., Lane, P.R., 1999. The voracity effect, American Economic Review, 89, 1: 22-46.

Torvik, R., 2002. Natural resources, rent seeking and welfare, Journal of Development Economics, 67: 455-70.

Tullock, G., 1980. Efficient rent seeking, in J. Buchanan, R. Tollison, and G. Tullock, (eds), Towards a Theory of the Rent-Seeking Society, College Station, Texas A\&M University Press, 97-112.

Victor, N., 2007. On measuring the performance of national oil companies (NOCs), mimeo, Stanford University.

Walter, B., 2009. Bargaining failures and civil war, Annual Review of Political Science, 12: 243-61.

Wolf, C., 2009. Does ownership matter? The performance and efficiency of state oil vs. private oil (19872006), Energy Policy, 37: 2642-52. 